Louisiana State University

LSU Digital Commons

8-28-2008

Diagnoses for Leiognathus Lacepède 1802, Equula Cuvier 1815, Equulites Fowler 1904, Eubleekeria Fowler 1904, and a New Ponyfish Genus (Teleostei: Leiognathidae)

Prosanta Chakrabarty

American Museum of Natural History

John S. Sparks

American Museum of Natural History

Follow this and additional works at: https://digitalcommons.Isu.edu/biosci_pubs

Recommended Citation

Chakrabarty, P., \& Sparks, J. (2008). Diagnoses for Leiognathus Lacepède 1802, Equula Cuvier 1815, Equulites Fowler 1904, Eubleekeria Fowler 1904, and a New Ponyfish Genus (Teleostei: Leiognathidae). American Museum Novitates (3623), 1-11. https://doi.org/10.1206/618.1

This Article is brought to you for free and open access by the Department of Biological Sciences at LSU Digital Commons. It has been accepted for inclusion in Faculty Publications by an authorized administrator of LSU Digital Commons. For more information, please contact ir@lsu.edu. 


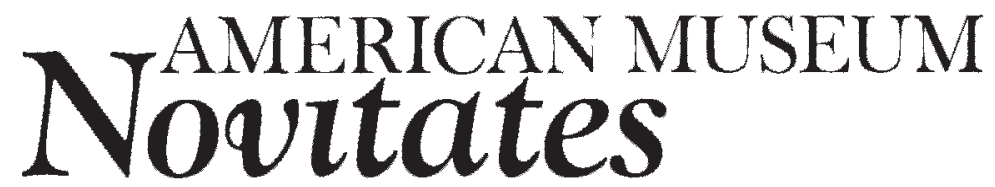

PUBLISHED BY THE AMERICAN MUSEUM OF NATURAL HISTORY CENTRAL PARK WEST AT 79TH STREET, NEW YORK, NY 10024 Number 3623, 11 pp., 7 figures

\title{
Diagnoses for Leiognathus Lacepède 1802, Equula Cuvier 1815, Equulites Fowler 1904, Eubleekeria Fowler 1904, and a New Ponyfish Genus (Teleostei: Leiognathidae)
}

\author{
PROSANTA CHAKRABARTY ${ }^{1}$ AND JOHN S. SPARKS ${ }^{1}$
}

\begin{abstract}
Recent phylogenetic work on ponyfishes has delimited and revealed the interrelationships of major leiognathid clades. To begin to recognize a monophyletic taxonomy for Leiognathidae we diagnose, delimit, and describe a number of ponyfish genera to reflect our current knowledge of their phylogenetic history. Equula Cuvier, 1815, is resurrected from synonymy with Leiognathus Lacepède, 1802, and comprises E. fasciata and E. longispinis. Members of Equula, the sister group to all other members of Leiognathidae, are large-bodied ponyfishes characterized by conspicuous round yellow blotches on the flank. The genus Leiognathus Lacepède, 1802, the sister group to the remaining members of Leiognathidae less Equula, is herein restricted to a clade comprising Leiognathus equulus, L. robustus, and L. striatus. The subgenus Equulites Fowler, 1904, comprising E. leuciscus, E. klunzingeri, and E. laterofenestra, is removed from synonymy with Leiognathus and is elevated to generic rank. The subgenus Eubleekeria Fowler, 1904 is removed from synonymy with Leiognathus and is likewise elevated to generic rank. Eubleekeria encompasses the "Leiognathus" splendens species complex, which is recovered as the sister group to Photopectoralis. To remedy the paraphyly of the remaining species placed within Leiognathus we describe a new genus, Karalla, which is recovered as the sister group to Nuchequula.
\end{abstract}

\section{INTRODUCTION}

Our knowledge of leiognathid intrarelationships has increased substantially due to the publication of several recent family-level phylogenetic analyses (Ikejima et al., 2004; Sparks and Dunlap, 2004; Sparks et al., 2005). It is noteworthy that all studies recover a

\footnotetext{
${ }^{1}$ Division of Vertebrate Zoology (Ichthyology), American Museum of Natural History (PC: prosanta@amnh.org; JSS: jsparks@amnh.org).
} 


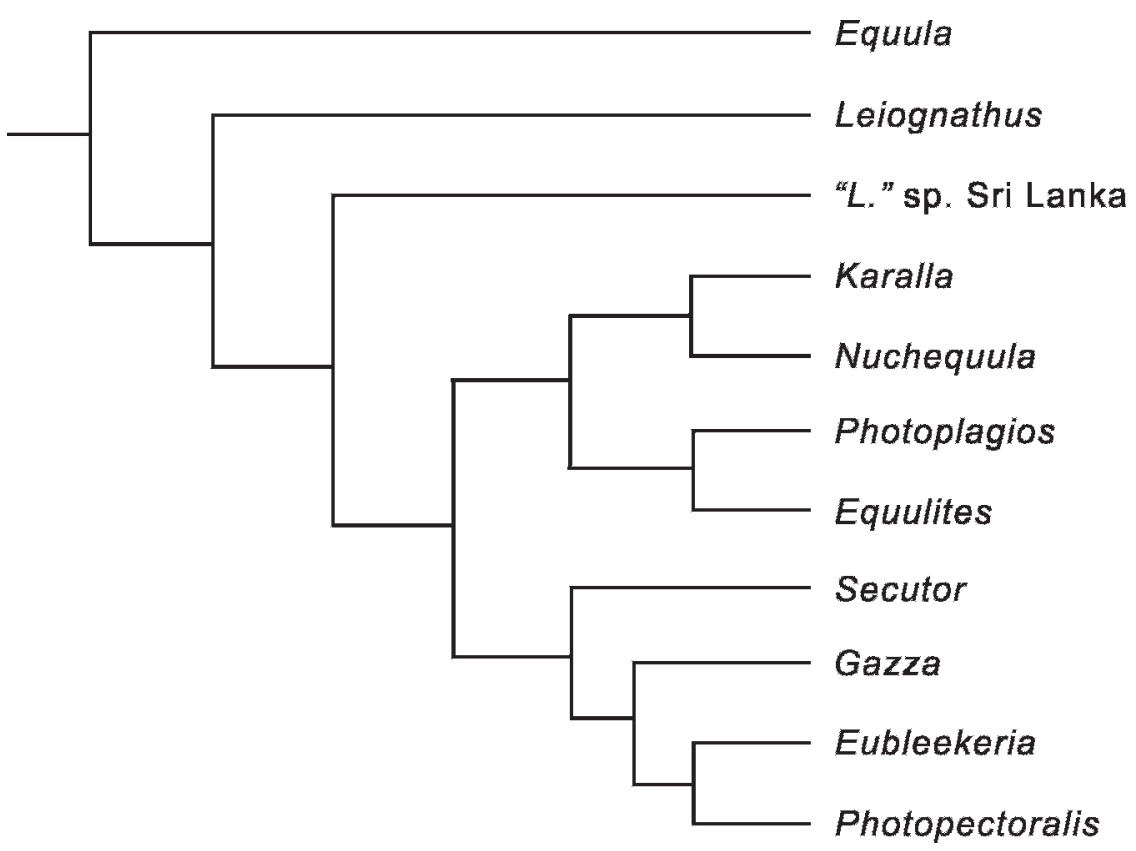

Fig. 1. Generic-level phylogeny for Leiognathidae based on Sparks et al. (2005) and Chakrabarty et al. (MS).

paraphyletic Leiognathus Lacepède, 1802. To begin to achieve a monophyletic taxonomy for Leiognathidae, a number of new genera have recently been described or resurrected from synonymy including: Nuchequula Whitley, 1932 (elevated to generic rank by Chakrabarty and Sparks, 2007), Photoplagios Sparks et al., 2005, and Photopectoralis Sparks et al., 2005.

Members of Leiognathidae are nondescript, silvery, generally small ( $<200 \mathrm{~mm}$ SL), laterally compressed fishes. Their mouths are highly protractible either dorsally, rostrally, or most commonly, ventrally. They possess five branchiostegals, VII-IX dorsal-fin spines (mode VIII) and 15-17 branched rays (mode 16), three anal-fin spines and 13-15 branched rays (mode 14), and 24 (10 precaudal +14 caudal) vertebral centra. These counts are consistent within the family and do not vary among species. Uniquely, all leiognathids possess a circumesophageal light organ that contains symbiotic luminescent bacteria (Photobacterium), whose light the fish co-opt for photic communication and predator avoidance (Hastings, 1971; McFall-Ngai and Dunlap, 1983). Most species are sexually dimorphic with regard to the light organ and associated structural features that facilitate the transmission of bacterially generated luminescence (i.e., the light-organ system: LOS; Sparks et al., 2005). Males of many species have a translucent lateral patch or patches on the head region or flank from which light is emitted (Sparks et al., 2005). Additional apomorphic anatomical features for the family include: broad, extremely thin cleithrum that is sheetlike ventrally; two distinct bony prongs along the anterior margin of the cleithrum (see below); broad and platelike neural and hemal spines on fourth preural centrum; and one or two unique spinous processes on the lateral ethmoid.

On the basis of a rigorous phylogenetic hypothesis for Leiognathidae, we continue instituting taxonomic changes here by resurrecting previously synonymized genera, naming novel genera, and by restricting Leiognathus Lacepède, 1802, to a monophyletic group (Sparks et al., 2005; Chakrabarty et al., Ms; fig. 1). Leiognathus has historically been a catchall genus whose monophyly had not been tested until recently. Figure 1 depicts a generic-level phylogeny for Leiognathidae 
based primarily on the analysis of Sparks et al., 2005.

\section{MATERIALS AND METHODS}

Osteological features were examined using radiographs, specimens cleared and stained (C\&S) for bone and cartilage (following Taylor and Van Dyke, 1985), and dry skeletal (S) preparations. Comparative materials are listed in Material Examined. Light organs were examined in situ or isolated via dissection to permit detailed morphological comparisons. Morphometric measurements were recorded to the nearest $0.1 \mathrm{~mm}$ using dial calipers. Standard length (SL) and body depth (BD) are used throughout.

\section{InSTITUTIONAL ABBREVIATIONS}

AMNH American Museum of Natural

$\begin{array}{ll} & \text { History, New York } \\ \text { AMS } & \text { Australian Museum, Sydney }\end{array}$

ANSP Academy of Natural Sciences, Philadelphia

ASIZ Academica Sinica Institute of Zoology, Taipei

BMNH British Museum of Natural History, London

CAS California Academy of Sciences, San Francisco

CUMZ Chulalongkorn University Museum of Zoology, Bangkok

LACM Los Angeles County Museum of Natural History, Los Angeles

MCZ Museum of Comparative Zoology, Cambridge

MNHN Muséum National d'Histoire Naturelle, Paris

NMW Naturhistorisches Museum, Wien

QM Queensland Museum, Brisbane

RMNH Nationaal Natuurhistorisch Museum, Leiden

USNM National Museum of Natural History, Smithsonian Institution, Washington, D.C.

UMMZ University of Michigan Museum of Zoology, Ann Arbor

WHT Wildlife Heritage Trust, Colombo, Sri Lanka

ZMB Universitat Humboldt, Museum fur Naturkunde, Berlin

ZMUC Kobenhavens Universitet Zoologisk Museum, Copenhagen

ZRC Raffles Museum of Biodiversity Research, Singapore

\section{SYSTEMATIC ACCOUNTS}

Leiognathus Lacepède, 1802

Figure 2

TyPe SPECIES: Leiognathus equulus (Forsskål, 1775).

Other Included Species: Leiognathus robustus Sparks and Dunlap, 2004, L. striatus, James and Badrudeen, 1990.

Diagnosis: Members of Leiognathus are distinguished from all other leiognathids by a combination of large adult body size $(>150 \mathrm{~mm} \mathrm{SL})$, the absence of large round blotches of pigment on the flank, and the presence of a strongly ventrally protracting mouth.

REMARKs: Members of Leiognathus can be further distinguished from all other ponyfishes, except Equula, by the presence of a nonsexually dimorphic light organ. The absence of flank pigmentation or the possession of faint yellowish or grayish-yellow vermiculate lines or vertical bars on the dorsal flank also distinguishes members of Leiognathus from all other ponyfishes, except Equula. Members of Leiognathus can be further distinguished from members of Equula by the presence of a strongly concave lower jaw profile (versus straight or nearly straight in Equula). All explicit phylogenetic studies of Leiognathidae to date have recovered a paraphyletic Leiognathus (Ikejima et al., 2004; Sparks and Dunlap, 2004; Sparks et al., 2005; Chakrabarty et al., Ms). In accordance with the results of these studies, we restrict the name Leiognathus to the clade containing the type species, Leiognathus equulus (Forsskål, 1775) (see Sparks and Dunlap, 2004), and two other described species, Leiognathus robustus Sparks and Dunlap, 2004, and Leiognathus striatus James and Badrudeen, 1990, a species rarely mentioned in the literature and even more rarely encountered in museum collections. This restricted concept of Leiognathus is recovered as the sister group to all other members of Leiognathidae, less Equula (fig. 1). Other ponyfish species in the literature currently referred to Leiognathus, but not included in our restricted concept of this genus, are provided novel or resurrected generic assignments below on the basis of apomorphic 

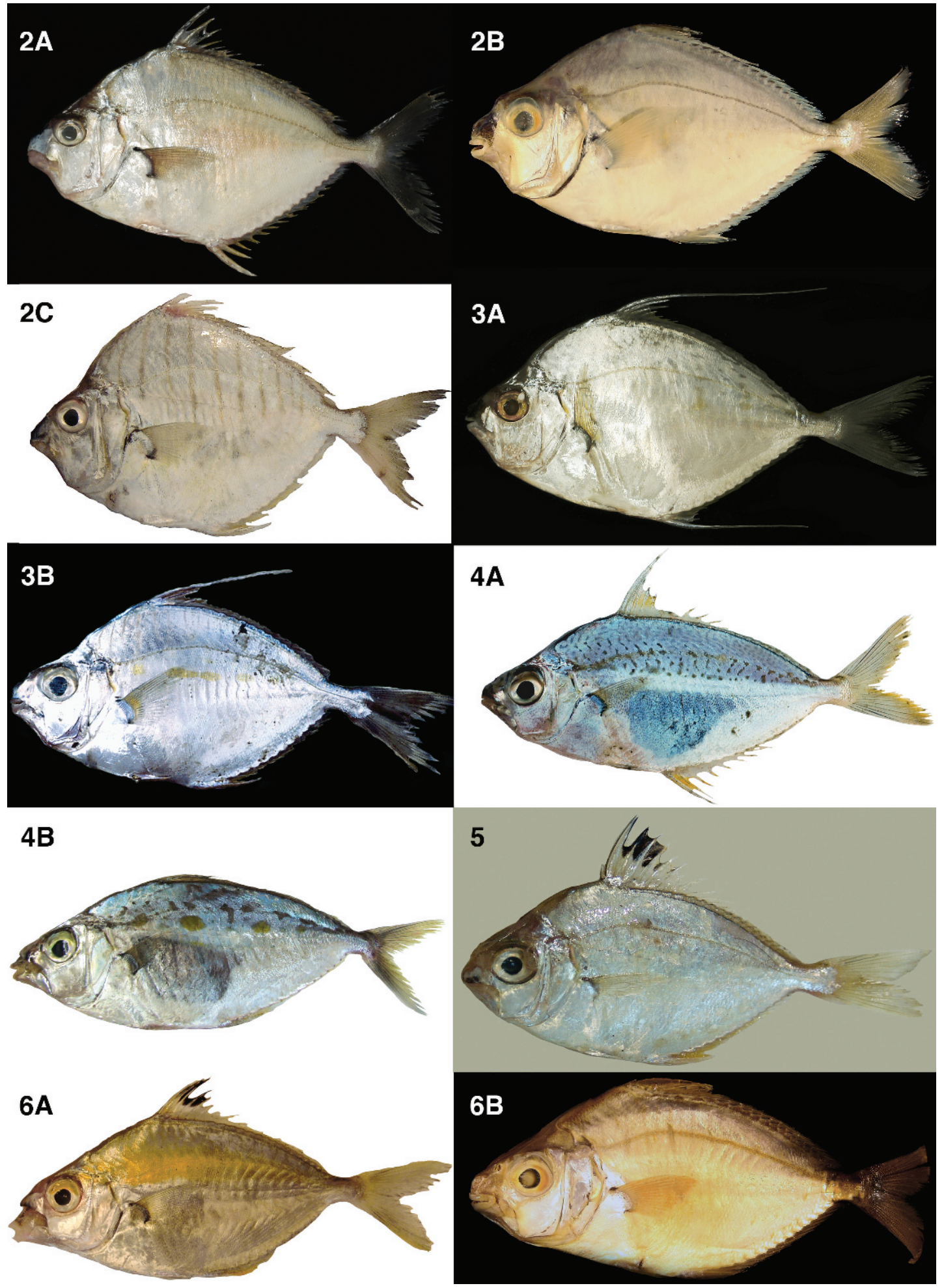
morphological features. The lineage labeled " "L.' sp. Sri Lanka" in figure 1 is recovered as a member of Leiognathus in Chakrabarty et al. (Ms). The taxonomy of this group is further dealt with in that manuscript rather than here, because the species-level status of " $L$." sp. Sri Lanka cannot be determined due to a lack of morphological vouchers (only a tissue sample was available to Sparks et al., 2005).

Leiognathus striatus can be distinguished from its congeners by the presence of an extremely deep body with a strongly convex dorsal profile (owing to the presence of a pronounced occipital hump) and a pigmentation pattern on the dorsal flank comprising broad yellow vertical bars. Leiognathus robustus can be distinguished from its congeners by the absence of a pronounced occipital hump and the presence of a mildly sloping predorsal profile (see Sparks and Dunlap, 2004). Leiognathus equulus is distinguished from congeners by the combination of a strongly sloping predorsal profile with a pronounced occipital hump and the absence of yellow vertical bars on the flank.

\section{Equula Cuvier, 1815}

Figure 3

Leiognathus fasciatus complex Clade I: Sparks et al., 2005.

TyPe SPECIES: Equula longispinis Valenciennes, in Cuvier and Valenciennes, 1835.

Other Included Species: Equula fasciata (Lacepède, 1803).

DiAgNosis: Members of Equula can be distinguished from all other leiognathids by the presence of a series of round yellow blotches arrayed horizontally along the flank.

Remarks: Members of Equula can be further distinguished from all other pony- fishes, except Leiognathus, by the presence of a nonsexually dimorphic light organ.

Sparks et al. (2005) recovered a clade they referred to as the "Leiognathus fasciatus complex" (Clade I in that study) as the sister group to the remaining members of Leiognathidae. The "Leiognathus fasciatus complex" of Sparks et al. (2005) included two nominal species, Leiognathus fasciatus and L. longispinis. The oldest available name for this group is Equula Cuvier, 1815, which is henceforth removed from synonymy with Leiognathus and assigned to this clade. Tortonese (1973) considered Equula Cuvier, 1815 , to be a junior synonym of Leiognathus Lacepède, 1802, but this synonymy was not based on an explicit comparative analysis. Because of the influence of the work of Cuvier and Valenciennes (1835), many species of leiognathids were initially described as members of Equula, and for much of the early part of the last century most leiognathid species were considered to be members of this genus.

The two species of Equula can be easily distinguished from each other by the presence of a markedly elongate $(\geq 60-100 \%$ of BD) second anal-fin spine in E. longispinis (vs. $<50 \%$ of BD in E. fasciata), a feature lacking in all other leiognathids (Jones, 1985; Sparks, 2006a).

A homonym, Equula longispina De Vis, 1884 exists for Equula longispinis Valenciennes, in Cuvier and Valenciennes, 1835, which is objectively invalid and was provided the replacement name of Leiognathus hastatus Ogilby, 1912 (Eschmeyer, 2007). Leiognathus hastatus Ogilby, 1912 (= Equula longispina De Vis, 1884) is considered to be a synonym of Photoplagios leuciscus (Günther, 1860; see Hoese and Bray, 2006, and Eschmeyer, 2007). Leiognathus smithursti (Ramsay and Ogilby, 1886) was recently deemed a junior

Figs. 2-6. Coloration of ponyfishes. 2A, Leiognathus equulus, AMNH 242134, 182.7 mm SL; coloration in life. 2B, Leiognathus robustus, UMMZ 242144, holotype, $183.4 \mathrm{~mm} \mathrm{SL}$; coloration in preservation. 2C, Leiognathus striatus, WHT PC-183, 173.6 mm SL; coloration in life. 3A, Equula longispinis, AMNH 242135, $160.6 \mathrm{~mm}$ SL; coloration in life. 3B, Equula fasciata, AMNH uncat., $119.2 \mathrm{~mm}$ SL, coloration in life. 4A, Equulites leuciscus, AMNH uncat., ca. $80 \mathrm{~mm}$ SL; coloration in life. 4B, Equulites laterofenestra, AMNH 241311, 100.1 mm SL; coloration in life. 5, Eubleekeria splendens, WHT PC-166, $68 \mathrm{~mm}$ SL, type species of genus; coloration in life. 6A, Karalla daura, WHT PC-187, 97.8 mm SL, type species of genus; coloration in life. 6B, Karalla dussumieri, MNHN A-6721, holotype; coloration in preservation. 
synonym of Equula longispinis (Sparks, 2006a).

\section{Equulites Fowler, 1904}

Figure 4

Photoplagios in part: Sparks et al., 2005; Sparks, 2006b; Sparks and Chakrabarty, 2007.

TyPe Species: Equulites leuciscus (Günther, 1860).

Other InCluded Species: Equulites klunzingeri (Steindachner, 1898), E. laterofenestra (Sparks and Chakrabarty, 2007).

Diagnosis: Members of Equulites are distinguished from all other leiognathids by the combination of an expansive translucent triangular, cornucopia-shaped or trapezoidal patch on the flank in males, a greatly elongate and feeble second dorsal-fin spine (more pronounced in males), and a pigmentation pattern on the dorsal flank comprising speckles and vermiculate markings or broad oblong markings that occasionally form open circular patterns.

REMARKS: Equulites was described by Fowler (1904: 516-517) as a subgenus of Leiognathus to encompass his newly described species Leiognathus vermiculatus Fowler, 1904, and L. virgatus Fowler, 1904. Leiognathus virgatus, a deep-bodied species, was subsequently synonymized with Leiognathus (now Photopectoralis) bindus (Valenciennes, 1835) by Woodland et al. (2001), whereas Leiognathus vermiculatus was synonymized with L. (now Equulites) leuciscus by Jones (1985: 590-591), a synonymy further corroborated by Sparks (2006b: 13). Herein we elevate Equulites, a strongly supported monophyletic assemblage (Sparks et al., 2005: fig. 1) comprising three nominal species, to generic rank. Equulites is a widespread genus, with members' distributions spanning nearly the entire geographic range of the family. Members of Equulites are sexually dimorphic with respect to light-organ volume and shape, with those of males being considerably larger than similarly sized conspecific females. Males also possess an expansive translucent triangular flank patch and corresponding clearing of the guanine-lined gas bladder, features lacking entirely in females.
Members of Equulites can easily be distinguished from Photoplagios, to which they were formerly assigned (Sparks et al., 2005), by pigmentation pattern on the dorsal flank (vermiculate and highly mottled in Equulites vs. much larger and more sparse oval blotches in Photoplagios; see Sparks and Chakrabarty, 2007: fig. 1), length of the second dorsal-fin spine (markedly elongate in Equulites), and degree of sexual dimorphism and morphology of the light organ (dorsal lobes of males moderately enlarged in males and extending only slightly into the gas bladder chamber in Equulites vs. dorsal lobes of males greatly enlarged and extending posteriorly well into the gas bladder chamber in Photoplagios). Sparks and Chakrabarty (2007: 627) present a number of diagnostic species-level features to distinguish members of this clade from congeners.

\section{Eubleekeria Fowler, 1904}

Figure 5

Leiognathus splendens complex: Kimura et al., 2005.

Clade H: Sparks et al., 2005.

TyPe SPecies: Eubleekeria splendens (Cuvier, 1829).

Other Included Species: Eubleekeria jonesi (James, 1971). E. kupanensis (Kimura and Peristiwady, 2005, in Kimura et al., 2005), E. rapsoni (Munro, 1964).

Diagnosis: Members of Eubleekeria are distinguished from all other leiognathids by the combination of a vermiculate dorsal flank pigmentation pattern, black markings in the membrane of the spinous dorsal fin, and the presence of chest scales.

ETYMOLOGY: Eubleekeria was named in honor of the prolific Dutch ichthyologist Pieter Bleeker by Fowler (1904: 516). Russell (1803) illustrated the fish that was later described as Equula splendens Cuvier, 1829 (who provided the binomial in a footnote referring to Russell's illustration), providing it with the common name "Goomorah Karah".

REMARKs: Eubleekeria was described by Fowler (1904: 516-517) as a subgenus of Leiognathus to encompass Leiognathus splendens (Cuvier, 1829) and Leiognathus spilotus Fowler, 1904, which was later synonymized 
with L. splendens by Kimura et al. (2005). Sparks et al. (2005: fig. 1) recovered "Clade H" (herein Eubleekeria) as the sister group to Photopectoralis. Herein we elevate this monophyletic assemblage to generic rank. Members of Eubleekeria are sexually dimorphic with respect to light-organ volume, with those of males being considerably larger than similarly sized conspecific females. Kimura et al. (2005) presented the following combination of characters in their diagnosis of this group: body deep $(42-60 \% \mathrm{SL})$; mouth protracting ventrally; jaw teeth slender, minute; lower margin of orbit above the horizontal through the gape when mouth closed; breast almost completely scaled; lateral line complete; dark blotch on top of spinous dorsal fin. Unfortunately, all of these features are more broadly distributed within Leiognathidae, and provide no diagnostic information for Eubleekeria. In addition, we find the mouth to protract only slightly downward in these species, as opposed to strongly downward as is the case with most other members of the family. The shape of the snout in Eubleekeria also appears to be unique, owing to the combination of a shorter snout length than in most leiognathids $(25-30 \%$ of HL; similar to Photopectoralis bindus, and members of Gazza and Secutor) and an orbital ridge that protrudes strongly dorsally. The four species of Eubleekeria can be distinguished by squamation pattern (on the cheek, chest, and predorsal region) as well as the extent of the dark blotch on the spinous portion of the dorsal-fin membrane (see Kimura et al., 2005, for diagnostic species-level features).

\section{Karalla, new genus}

Figure 6

Clade G, in part: Sparks et al. 2005.

Type Species: Karalla daura (Cuvier, 1829).

Other Included SPecies: Karalla dussumieri (Valenciennes, in Cuvier and Valenciennes, 1835).

Diagnosis: Members of Karalla are distinguished from all other leiognathids by either the presence of a deep golden coloration on the flank or a weakly retrognathous lateral snout outline.

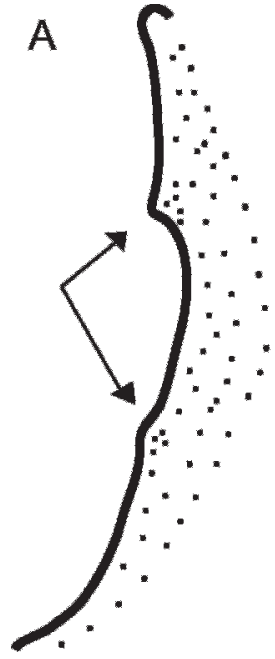

B

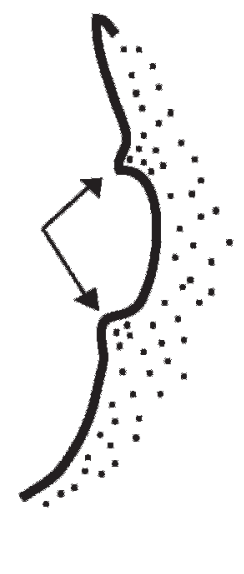

$1 \mathrm{~cm}$

Fig. 7. Lateral view of anterodorsal margin of left cleithrum showing two pronglike protuberances as observed in (A) Eubleekeria splendens, CAS 56441, $95.7 \mathrm{~mm}$ SL, and more highly developed state in (B) Karalla daura, ANSP 89582, 85.1 $\mathrm{mm}$ SL.

Etymology: Karalla is the local name for ponyfishes in Sri Lanka and the surrounding region where members of this genus commonly occur. This generic epithet is genderneutral.

REMARKS: Karalla can be further distinguished from other leiognathids by the combination of a scaled nuchal region, an elongate rhomboid body, and the presence of two welldeveloped (vs. weak) prongs on the anterodorsal margin of the cleithrum (fig. 7). The presence of two prongs on the anterodorsal margin of the cleithrum is a synapomorphy of Leiognathidae; however, this feature is more prominent in Karalla than most other genera (fig. 7). Members of Karalla also possess a distinct golden or deep yellowish-green coloration in life that differs from the bright yellow coloration of some species of Nuchequula.

The relationship between Karalla and Nuchequula was unresolved in the analysis of Sparks et al. (2005; Karalla daura was recovered as more closely related to Nuchequula than to $K$. dussumieri); however, members of both genera were recovered together as a monophyletic group in that study. Nuchequula is recovered with strong support as the sister group to Karalla in the 
phylogenetic analysis of Chakrabarty et al. (MS). This clade comprising Karalla and Nuchequula is in turn recovered as the sister group to Photoplagios (fig. 1). Karalla can be easily distinguished from Nuchequula by the absence of a prominent nuchal marking, whereas the presence of a nuchal marking is a synapomorphy of the latter genus (Chakrabarty and Sparks, 2007).

Karalla daura can easily be distinguished from all other leiognathids by the presence of enlarged fleshy lips and by the presence of a broad, golden horizontal stripe along the midline of the flank, which surrounds the entire lateral line from the orbit to the caudal peduncle, and is as deep as the arc of the lateral line vertically (fig. 6A). In contrast, $K$. dussumieri lacks a distinct golden stripe. Instead, a diffuse golden coloration is present on the flank punctuated by dark, yellow-green vermiculate lines over the dorsal half of the body. In addition, $K$. daura also possesses a large dark blotch on the spinous dorsal-fin membrane, a feature lacking in $K$. dussumieri (fig. 6B).

\section{MATERIAL EXAMINED}

Gazza achlamys: CAS-SU 21652, paratype, 1 ex.; CAS-SU 22853, paratype, 1 ex.; UMMZ 240128; UMMZ 240132; UMMZ 240139. Gazza dentex: MNHN A-578, lectotype. Gazza minuta: AMNH 220748; AMNH 237136; UMMZ 191542; UMMZ 240126; UMMZ 240140; UMMZ 240141; UMMZ uncat. Gazza rhombea: USNM 332347, paratype, 1 ex.; USNM 350467, paratype, 1 ex. Gazza squamiventralis: USNM 345525, holotype; USNM 345526, paratype, 1 ex.; AMNH 237137.

Equula fasciata: AMNH 15520; AMNH 237140; AMNH 241338; CAS 1872; UMMZ 240504; AMNH 240597; AMNH uncat.; USNM 191962; USNM 191966; WHT PC-195; WHT PC-196; WHT PC-197. Equula longispinis: MNHN A-0579, holotype; AMNH 219296; AMNH 242135; AMNH uncat. (SI-87); AMS I.20907036; AMS I.22974001; AMS 22981001; AMS 23044001; USNM 324651; ZRC 50950.

Equulites klunzingeri: NMW 68277, syntypes, 4 ex.; NMW 68280, syntypes, 2 ex.;
NMW 76008, syntypes, 4 ex.; NMW 76009, syntypes, 4 ex.; AMNH 44488; AMNH 44491; AMNH 44493. Equulites laterofenestra: USNM 387899, holotype; USNM 228508, paratypes, 4 ex.; AMNH 238682, paratypes, 2 ex.; AMNH 241277; AMNH 241311; AMNH 241315; AMNH 241352; WHT PC132; WHT PC-133; WHT PC-188. Equulites leuciscus: BMNH 1858.4.21.243, holotype; AMNH 237149; AMNH 239270; AMNH 240587; AMNH 240589; AMNH 241278; AMNH 241313; AMNH 242666; AMS I.22967001; AMS I.22978004; AMS I.34365015; ANSP 27525 (holotype of "Leiognathus" vermiculatus); UMMZ 240125; UMMZ uncat.; USNM 76609; USNM 191979; USNM 191991; USNM 307917; USNM 373280; QM.I. 878 (holotype of "Equula" longispina).

Eubleekeria jonesi: AMNH 241302; AMNH 241339; AMNH 241359; UMMZ 235095; UMMZ 240134; UMMZ 240505; UMMZ uncat. Eubleekeria kupanensis: UMMZ 243701. Eubleekeria splendens: AMNH 241339; ANSP 59963; ANSP 27530; ANSP 47486 (holotype of "Leiognathus" philippinus); ANSP 47487; CAS 1485; CAS 38789; CAS 56438; CAS 56441; MNHN A-6724; UMMZ 191202; UMMZ 240130, UMMZ uncat.; USNM 190258; USNM 190263; WHT PC-136; WHT PC-137; WHT PC-166; WHT PC-191.

Karalla daura: AMNH 241316; ANSP 89582; USNM 100291; USNM 373281; WHT PC-131; WHT PC-170; WHT PC-187. Karalla dussumieri: MNHN A-6721, syntype, 1 ex.; AMNH 234763; WHT PC-130; WHT PC-134; WHT PC-135; WHT PC-161; WHT PC-162; WHT PC-190.

Leiognathus equulus: ZMUC P48219, lectotype (dry skin; photographs and radiographs examined); ZMUC P48220, paralectotype (dry skin, photograph and radiograph examined); ZMB 8756 (holotype of "Leiognathus" edentulus); AMNH 59535; AMNH 88039; AMNH 237139; AMNH 242134; CAS 57306; CAS-SU 35627; CAS-SU 38781; MNHN A-6723; UMMZ 191520; UMMZ 235029; UMMZ 238805 (in part); UMMZ 240133; UMMZ 240502; UMMZ 240503; UMMZ uncat. Leiognathus robustus: UMMZ 242144, holotype; AMNH 233607, 1 ex., paratype; UMMZ 240362, 1 ex, paratype.; UMMZ 240360; Leiognathus striatus: SU 22909; WHT PC- 
183; WHT PC-184; WHT PC-192; WHT PC193; WHT PC-194.

Nuchequula blochii: MNHN A-6757, syntype, 1 ex.; MNHN A-6759, syntype, 1 ex. Nuchequula decora: AMNH 231297, AMS I.22990002. Nuchequula mannusella: AMNH 238753, holotype; AMNH 238754, paratypes, 15 ex.; AMNH 238755, paratypes; 16 ex.; AMNH 238756, paratypes, 15 ex.; AMNH 238757, paratypes, 14 ex.; AMNH 238758, paratypes; 20 ex.; AMNH 238759, paratypes, 9 ex.; AMNH 238760, paratypes, 13 ex.; AMNH 238761, paratypes, 1 ex.; AMNH 238762, paratype, 1 ex.; AMNH 238763, paratypes; 1 ex.; AMNH 238764, paratype, 1 ex.; AMNH 238765, paratypes, 29 ex.; ASIZP0062322, paratype, 1 ex.; ASIZP0060823, paratype; 1 ex.; ASIZP0059839, 2 ex.; ASIZP0065686. Nuchequula nuchalis: RMNH 1287, holotype; AMNH 26819; AMNH 34861, AMNH 26819; AMNH 238766; CAS-SU 4757; UMMZ 240143. Nuchequula pan: CUMZ 2528.2.9.1, holotype; CUMZ 2528.2.9.2, paratype, 1 ex.; CUMZ 2528.2.9.3, paratype, 1 ex.; USNM 276536, paratype, 1 ex.

Photopectoralis aureus: UMMZ 240129; UMMZ 240309; UMMZ uncat.; USNM 373277. Photopectoralis bindus: AMS I.34367021, CAS 51097; UMMZ 240131; UMMZ 240142; UMMZ uncat.; USNM 373284; MNHN A-6763 (syntype of "Equula" brevirostris). Photopectoralis cf. bindus: AMNH 237147. Photopectoralis hataii: UMMZ uncat. Photopectoralis cf. hataii: AMNH 89922. Photopectoralis panayensis: UMMZ 240300, holotype; UMMZ 240301, paratypes, 4 ex.; UMMZ 240302, paratypes, 5 ex.; UMMZ 240303, paratypes, 8 ex.; UMMZ 240304, paratypes, 16 ex.; UMMZ 240137; UMMZ uncat.

Photoplagios antongil: AMNH 236544, holotype; AMNH 236545, paratypes, 3 ex. Photoplagios elongatus: BMNH 1872.4.6.105, holotype; CAS 52602; LACM 42993-1; LACM 43584-1; SIO 83-55; USNM 55613; UMMZ 226771; UMMZ 240145; UMMZ uncat. Photoplagios moretoniensis: QM I.1583, syntype, 1 ex.; AMS I.21700001; AMS I.22983001. Photoplagios rivulatus: AMNH 34850; UMMZ 182938; UMMZ 240144; UMMZ uncat. ?Photoplagios ("Leiognathus") oblonga: MNHN A-6754, holotype. ?Photoplagios ("Leiognathus") parviceps:
MNHN A-0580, syntype, 1 ex. ?Photoplagios sp.: MNHN 1988-0327. Photoplagios stercorarius: USNM 55906, holotype; USNM 126395, cotype; ANSP 33289, paratype, 1 ex.; CAS 42171, paratype; CAS 17678; CASSU 20004, paratype; UMMZ 240138; UMMZ uncat.; USNM 191996; ZRC 50951.

Secutor indicius: UMMZ 240127; UMMZ uncat. Secutor insidiator: CAS 29894; UMMZ uncat. Secutor megalolepis: UMMZ 240135. Secutor ruconius: CAS-SU 29895; UMMZ 225240; UMMZ uncat.

\section{ACKNOWLEDGMENTS}

We thank Jeff Seigel (LACM) who first brought to our attention the bony protuberances on the cleithrum of ponyfishes. We also thank Jeff Johnson (QM); John Lundberg and Mark Sabaj (ANSP); Jeff Leis, Mark McGrouther, and Tom Trnski (AMS); Guy Duhamel and Patrice Provost (MNHN); Salince (Jeab) Khachonpisitsak, Somsak Panha, and Thosaporn Wongratana (CUMZ); Kwang-Tsao Shao, Hsuan-Ching Ho, and Leon Yun-Chih Liao (ASIZ); Lynne Parenti and Jeff Williams (USNM); David Catania and William Eschmeyer (CAS); Kelvin Lim, Heok Hee $\mathrm{Ng}$ and Peter $\mathrm{Ng}$ (ZRC); and William Fink and Douglas Nelson (UMMZ) for the loan of material in their care. Collections from Taiwan were made with the generous assistance of Hin-Kiu Mok, Joker K.H. Chiu, Otto Jeng-Di Lee, Yun-Chih Liao, Kwang-Tsao Shao, Ya-Wen Chen, Huck Shu Huai Liu, Hsuan-Ching Ho and Yi-Jing Ho. Rohan Pethiyagoda kindly provided resources to facilitate our Sri Lankan fieldwork and has maintained specimens at the Wildlife Heritage Trust of Sri Lanka. Thasun Amarasinghe provided field assistance in Sri Lanka. Daniel Lumbantobing and Renny Hadiaty provided resources and helped with collecting efforts in Indonesia. Bella S. Galil provided specimens from Israel. Radford Arrindell, Barbara Brown, and Scott Holtz helped with loans, cataloging, and other aspects of collection management. This work was supported by a grant (DEB0444842) from the National Science Foundation. 


\section{REFERENCES}

Chakrabarty, P., and J.S. Sparks. 2007. Phylogeny and taxonomic revision of Nuchequula Whitley 1932 (Teleostei: Leiognathidae), with the description of a new species. American Museum Novitates 3588: 1-25.

Chakrabarty, P., W.L. Smith, and J.S. Sparks. ms. The leiognathid light organ system: sexual selection, morphological diversification and speciation in ponyfishes (Teleostei: Leiognathidae). 27 pp., 3 figs.

Cuvier, G. 1815. Observations et recherches critiques sur différents poissons de la Méditerrannée, et à leur occasion sur des poissons d'autres mers, plus ou moins liés avec eux. Memoirs du Museum National d'Histoire Naturelle 1: 226-241, 312-330, 353-363, 451-466, pls. 16, 23.

Cuvier, G. 1829. Le règne animal, distribué d'après son organisation, pour servir de base à l'histoire naturelle des animaux et d'introduction à l'anatomie comparée. Ed. 2 v. 2: i-xv + 1-406.

Cuvier, G., and A. Valenciennes. 1835. Histoire naturelle des poissons. v., 10 : $1-x x i v+1-482+2$ pp., pls. 280-306.

De Vis, C.W. 1884. On new fishes from Moreton Bay. Proceedings of the Royal Society of Queensland 1: 144-147.

Eschmeyer, W. 2007. Catalogue of fishes. Updated October 9, 2007 (http://www.calacademy.org/ research/ichthyology/catalog/fishcatsearch.html).

Forsskål, P. 1775. Descriptiones animalium avium, amphibiorum, piscium, insectorum, vermium; quae in itinere orientali observavit. Post mortem auctoris edidit Carsten Niebuhr: $1-20+\mathrm{i}-$ xxxiv + 1-164, Hauniae [Copenhagen]: Möller.

Fowler, H.W. 1904. A collection of fishes from Sumatra. Journal of the Academy of Natural Sciences, Philadelphia 12(4): 495-560, pls. $7-$ 28.

Günther, A. 1860. Catalogue of the acanthopterygian fishes in the collection of the British Museum. 2. Squamipinnes, Cirrhitidae, Triglidae, Trachinidae, Sciaenidae, Polynemidae, Sphyraenidae, Trichiuridae, Scombridae, Carangidae, Xiphiidae. London: British Museum, 548 pp.

Hastings, J.W. 1971. Light to hide by: ventral luminescence to camouflage the silhouette. Science 173: 1016-1017.

Hoese, D.F., and D.J. Bray. 2006. Leiognathidae. In D.F. Hoese, D.J. Bray, G.R. Allen, J.R. Paxton, A. Wells and P.L. Beesley (editors), Fishes. Zoological Catalogue of Australia 35, parts 1-3, pages 1-2178. Collingwood, Victoria, Australia: ABRS and CSIRO Publishing.

Ikejima, K., N.B. Ishiguro, M. Wada, K. KitaTsukamoto, and M. Nishida. 2004. Molecular phylogeny and possible scenario of ponyfish (Perciformes: Leiognathidae) evolution. Molecular Phylogenetics and Evolution 31: 904-909.

James, P.S.B.R. 1971. A new species of silver-belly, Leiognathus jonesi (Family Leiognathidae: Pisces) from the Indian seas. Journal of the Marine Biological Association of India 11: 316-319.

James, P.S.B.R., and M. Badrudeen. 1990. A new species of silverbelly Leiognathus striatus (Family Leiognathidae: Pisces) from the Gulf of Mannar, India and redescription of Leiognathus fasciatus (Lacepède). Journal of the Marine Biological Association of India 32: 217-226.

Jones, G. 1985. Revision of the Australian species of the fish family Leiognathidae. Australian Journal of Marine and Freshwater Research 36: 559-613.

Kimura, S., T. Ito, T. Peristiwady, Y. Iwatsuki, T. Yoshino, and P.V. Dunlap. 2005. The Leiognathus splendens complex (Perciformes: Leiognathidae) with the description of a new species, Leiognathus kupanensis Kimura and Peristiwady. Ichthyological Research 52: 275-291.

Lacepède, B.G.E. 1802. Histoire naturelle des poissons 4. Paris: Plassan.

Lacepède, B.G.E. 1803. Histoire naturelle des poissons. Histoire naturelle des poissons 5 . Paris: Plassan.

McFall-Ngai, M.J., and Dunlap, P.V. 1983. Three new modes of luminescence in the leiognathid fish Gazza minuta: discrete projected luminescence, ventral body flash, and buccal luminescence. Marine Biology 73: 227-237.

Munro, I.S.R. 1964. Additions to the fish fauna of New Guinea. Papua New Guinea Agricultural Journal 16: 141-186.

Ogilby, J.D. 1912. On some Queensland fishes. Memoirs of the Queensland Museum 1: 26-65.

Ramsay, E.P., and J.D. Ogilby. 1886. A contribution to the knowledge of the fish-fauna of New Guinea. Proceedings of the Linnaean Society of New South Wales 1: 8-20.

Russell, P. 1803. Descriptions and figures of two hundred fishes; collected at Vizagapatam on the coast of Coromandel. London: W. Bulmer.

Sparks, J.S. 2006a. Leiognathus longispinis (Valenciennes, in Cuvier and Valenciennes, 1835), a senior synonym of Leiognathus smithursti (Ramsay and Ogilby, 1886) (Teleostei: Leiognathidae). Copeia 2006: 539-543.

Sparks, J.S. 2006b. A new species of ponyfish (Teleostei: Leiognathidae: Photoplagios) from Madagascar, with a phylogeny for Photoplagios and comments on the status of Equula lineolata 
Valenciennes. American Museum Novitates 3526: $1-21$.

Sparks, J.S., and P.V. Dunlap. 2004. A clade of non-sexually dimorphic ponyfishes (Teleostei: Perciformes: Leiognathidae): phylogeny, taxonomy, and description of a new species. American Museum Novitates 3459: 1-21.

Sparks, J.S., P.V. Dunlap, and W.L. Smith. 2005. Evolution and diversification of a sexually dimorphic luminescent system in ponyfishes (Teleostei: Leiognathidae), including diagnoses for two new genera. Cladistics 21: 305-327.

Taylor, W.R., and G.C. Van Dyke. 1985. Revised procedures for staining and clearing small fishes and other vertebrates for bone and cartilage study. Cybium 9: 107-119.

Tortonese, E. 1973. Leiognathidae. In J.C. Hureau and T. Monod (editors), Catalogue des pois- sons de l'Atlantique du nord-est et de la Méditerranée (Clofnam). Vol. 1: 390 pp. Paris: Unesco.

Valenciennes, A. 1835. Des Equula. In G. Cuvier and A. Valenciennes (editors), Histoire naturelle des poissons. Vol. 10: 60-103, pls. 283-284. Paris: F.G. Levrault.

Whitley, G.P. 1932. Some fishes of the family Leiognathidae. Memoirs of the Queensland Museum 10: 99-116.

Woodland, D.J., S. Premcharoen, and A.S. Cabanban. 2001. Leiognathidae: Slipmouths (ponyfishes). In K.E. Carpenter and V.H. Niem (editors), Species identification guide for fishery purposes. The living marine resources of the Western Central Pacific. Bony fishes part 3 (Menidae to Pomacentridae), 2792-2823. Rome: FAO. 
Complete lists of all issues of the Novitates and the Bulletin are available at World Wide Web site http://library.amnh.org/pubs. Inquire about ordering printed copies via e-mail from scipubs@amnh.org or via standard mail from: American Museum of Natural History, Library-Scientific Publications, Central Park West at 79th St., New York, NY 10024. TEL: (212) 769-5545. FAX: (212) 769-5009.

This paper meets the requirements of ANSI/NISO Z39.48-1992 (Permanence of Paper). 